\title{
Preservation of RNA and DNA from mammal samples under field conditions
}

\author{
MIGUEL CAMACHO-SANCHEZ,* PABLO BURRACO, † IVAN GOMEZ-MESTRE† and JENNIFER A. \\ LEONARD* \\ *Conservation and Evolutionary Genetics Group, Estación Biológica de Dorrana (EBD-CSIC), C/Américo Vespucio, s/n, 41092 \\ Seville, Spain, †Ecology, Evolution, and Development Group, Estación Biológica de Domana (EBD-CSIC), \\ C/Américo Vespucio, s/n, 41092 Seville, Spain
}

\begin{abstract}
Ecological and conservation genetics require sampling of organisms in the wild. Appropriate preservation of the collected samples, usually by cryostorage, is key to the quality of the genetic data obtained. Nevertheless, cryopreservation in the field to ensure RNA and DNA stability is not always possible. We compared several nucleic acid preservation solutions appropriate for field sampling and tested them on rat (Rattus rattus) blood, ear and tail tip, liver, brain and muscle. We compared the efficacy of a nucleic acid preservation (NAP) buffer for DNA preservation against 95\% ethanol and Longmire buffer, and for RNA preservation against RNAlater (Qiagen) and Longmire buffer, under simulated field conditions. For DNA, the NAP buffer was slightly better than cryopreservation or 95\% ethanol, but high molecular weight DNA was preserved in all conditions. The NAP buffer preserved RNA as well as RNAlater. Liver yielded the best RNA and DNA quantity and quality; thus, liver should be the tissue preferentially collected from euthanized animals. We also show that DNA persists in nonpreserved muscle tissue for at least 1 week at ambient temperature, although degradation is noticeable in a matter of hours. When cryopreservation is not possible, the NAP buffer is an economical alternative for RNA preservation at ambient temperature for at least 2 months and DNA preservation for at least 10 months.
\end{abstract}

Keywords: degradation, field sampling, NAP buffer, RNAlater, tissue storage

Received 31 October 2012; revision received 18 March 2013; accepted 21 March 2013

\section{Introduction}

It is critical to all genetic studies based on field samples to preserve them properly from point of collection to the laboratory. Good preservation of samples that may be used for genomic studies is even more important because many genomic protocols require a high quantity of highquality nucleic acids (Wong et al. 2012). Genomic techniques such as next-generation sequencing are becoming increasingly popular because they have allowed researchers to expand from transcriptome and genome experiments on model organisms in the laboratory, to applying these tools to specific ecological and evolutionary questions in nonmodel organisms in the wild (Dassanayake et al. 2009; Elmer et al. 2010; Hohenlohe et al. 2010; Wolf et al. 2010; Chen et al. 2011). However, many interesting biological samples for molecular ecology

Correspondence: Miguel Camacho-Sanchez, Fax: (+34) 954621125; E-mail: miguel.camacho@ebd.csic.es occur in locations where their preservation for genetic and expression studies is difficult, and cryopreservation is not possible. In this context, preservation of high-quantity and high-quality DNA and RNA under field conditions is fundamental to many new molecular ecology studies.

DNA and RNA degrade with increased time and temperature (Ludes et al. 1993; Vincek et al. 2003; Seear \& Sweeney 2008), and RNA degrades more rapidly than DNA (Massie et al. 1972). The best way to preserve RNA is to snap-freeze samples in liquid nitrogen followed by storage at $-80{ }^{\circ} \mathrm{C}$ (Gorokhova 2005; Wang \& Sherman 2006; Riesgo et al. 2012). However, cryopreservation in the field can be difficult or impossible. Stabilizing buffers such as RNAlater (Qiagen) can preserve RNA at ambient temperature (Vincek et al. 2003; Gorokhova 2005; Gayral et al. 2011). However, they are expensive and fieldwork often extends beyond time and/or temperature conditions suggested by the manufacturers (i.e. RNAlater is approved for storing tissue 
samples 4 weeks at $2-8{ }^{\circ} \mathrm{C}$, up to 7 days at $15-25^{\circ} \mathrm{C}$ or up to 1 day at $37^{\circ} \mathrm{C}$ ).

Cryopreservation is also the best way to preserve DNA (Nagy 2010; Wong et al. 2012). However, it is possible to recover high molecular weight DNA from vertebrate tissue preserved at ambient temperature for field appropriate times (Nietfeldt \& Ballinger 1989; Seutin et al. 1991; Muralidharan \& Wemmer 1994; Kilpatrick 2002; Nagy 2010; Michaud \& Foran 2011). Opportunistic encounters with animal carcasses in the wild also provide sampling opportunities from which it might be possible to recover high-quality DNA.

Here, we test RNA and DNA preservation from rat tissue under different preservation conditions as if they had been collected in the field: collection of samples with appropriate field tools in the open air and mid-termed preservation (7-8 weeks and 10 months) at ambient temperature. We compared the quality and quantity of RNA extracted from various sample types preserved in a homemade nucleic acid preservation (NAP) buffer, in RNAlater (Qiagen) or in Longmire buffer (Longmire et al. 1997). We also evaluated the quality and quantity of DNA extracted from samples preserved in NAP buffer, in 95\% ethanol or in Longmire buffer. We tested the preservation conditions on samples commonly obtained when animals are euthanized (liver, brain and muscle) or when the animal is released (ear, tail and blood). We also studied the postmortem stability of nonpreserved DNA in samples taken from muscle left at room temperature for up to 2 weeks.

\section{Materials and methods}

Three rats (Rattus rattus) were captured and euthanized as pest control in a private garden (Seville province, Spain) and donated by the owners. Within $25 \mathrm{~min}$ after death, several samples were taken from each individual in the following order: blood from cardiac puncture, liver, brain, muscle from the hind legs, ear and tail tip. Collectors were trained to sample around $6 \mathrm{~mm}^{2}$ from ear and 50-90 mg for the other sample types. Samples were placed in 1.5-mL Eppendorf tubes and preserved in five different ways: (i) snap-frozen in liquid nitrogen and then stored at $-80{ }^{\circ} \mathrm{C}$; (ii) $95 \%$ ethanol; (iii) Longmire buffer (Longmire et al. 1997); (iv) RNAlater (Qiagen); and (v) NAP buffer. Preservation at $-80{ }^{\circ} \mathrm{C}$ was used as a positive control for DNA and RNA preservation. The NAP buffer consisted of 0.019 м ethylenediaminetetraacetic acid (EDTA) disodium salt dihydrate, $0.018 \mathrm{M}$ sodium citrate trisodium salt dihydrate, $3.8 \mathrm{~m}$ ammonium sulphate and was adjusted to $\mathrm{pH} 5.2$ with $\mathrm{H}_{2} \mathrm{SO}_{4}$ (see Appendix I for the full protocol).

\section{RNA preservation}

The samples collected to study RNA preservation were left at ambient temperature for about 8 weeks (59-66 days) or about 10 months (294 days). We then extracted RNA from blood, liver, brain and ear samples using the PureLink ${ }^{\mathrm{TM}}$ RNA Mini Kit (Ambion, Life Technologies) and from muscle using the RNeasy Fibrous Tissue MiniKit (Qiagen), following the manufacturers' protocols. For the second time point, only liver and ear were available. They were cut in half and RNA was extracted from each in independent reactions.

RNA concentration was determined from the extracts with a NanoDrop ND-1000 Spectrophotometer (NanoDrop Technologies, Inc., Wilmington, DE, USA). The RNA quality was quantified in a 2100 BioAnalyzer (Applied Biosystems), which determines the RNA integrity number (RIN). This parameter estimates the RNA integrity on a scale from 1 (RNA is completely degraded) to 10 (RNA shows no degradation) as a function of the RNA electrophoretic profile (Schroeder et al. 2006).

\section{DNA preservation}

The samples collected to study DNA preservation were left at ambient temperature for about 7 weeks (49-51 days) or about 10 months (298 days). Liver, brain, muscle and tail tip samples were digested overnight at $37^{\circ} \mathrm{C}$ with proteinase K (Roche Diagnostics, Germany), and then, DNA was extracted using the High Pure PCR Template Preparation Kit (Roche Diagnostics, Germany) following the manufacturer's protocol. For the second time point (10 months), only brain and tail were available. They were cut in half and the DNA of each was extracted in independent reactions. We determined DNA concentrations and quality of the extractions with a NanoDrop ND-1000 Spectrophotometer and ran 1\% agarose gels stained with $\mathrm{SYBR}^{\circledR} \mathrm{SAFE}$ (Invitrogen, USA) to assess DNA degradation.

\section{Postmortem stability of DNA}

Muscle samples were left at room temperature in 1.5-mL Eppendorf tubes and snap-frozen in liquid nitrogen at times 0 h, 2 h, 6 h, 12 h, 24 h, 48 h, 1 week and 2 weeks, after which they were stored at $-80{ }^{\circ} \mathrm{C}$. The DNA extraction, quantification and quality assessment were done as above.

\section{Data analysis}

The effects of sample type and preservation conditions on the RNA quality (RIN) and quantity and on the DNA quantity were assessed by fitting generalized linear 
models, adopting Gaussian or negative binomial error distributions (with either identity or log link functions, respectively) as they best fit each variable. TukeyKramer post hoc tests were then conducted to test for differences among the different levels of each factor. We tested the effect of variation among rat individuals on the quantity of RNA and DNA and on the RNA quality across tissues and found it to be not significant in any case. Hence, we did not include rat identity in any further analysis. All analyses were run in SAs v. 9.1 (SAS Institute Inc., USA).

\section{Results}

\section{RNA preservation}

RNA from cryopreserved samples showed very little degradation as indicated by the BioAnalyzer. All cryopreserved samples except blood had two clear $18 \mathrm{~S}$ and $28 \mathrm{~S}$ peaks and high RIN values (mean T SD: 8.6 T 0.8; Table 1). Blood samples had a profile with two clear $18 \mathrm{~S}$ and $28 \mathrm{~S}$ peaks, but very low RNA concentration (mean T SD: 20.8 T $19.2 \mathbf{n g} \mathbf{l} \mathrm{L}$; Table 1), such that the BioAnalyzer software was not able to calculate RIN values. All samples from liver, muscle, brain and ear preserved in RNAlater and NAP buffer for 8 weeks were partially degraded as revealed by their electrophoretic profiles (i.e. Fig. 2). They all showed a clear $18 \mathrm{~S}$ peak, but a very low or no $28 \mathrm{~S}$ peak. We excluded two of the three muscle samples preserved in RNAlater from our results because they showed very low electrophoretic profiles, probably due to RNA extractions that did not work properly (see discussion). Samples preserved in RNAlater and NAP buffer experienced similar degradation for the same time point, but there was substantial RNA degradation between 8 weeks and 10 months (Figs 1 and 2; Table 1).

Extractions from cryopreserved samples had 1.5 times higher RNA concentration than those preserved in

Table 1 Mean RNA or DNA concentration (ng/lL T SD) for each rat sample type and preservation condition. For RNA, we also report the RNA integrity number (RIN) as a measure of quality. For $-80^{\circ} \mathrm{C}$, samples were snap-frozen in liquid nitrogen and then stored at $-80{ }^{\circ} \mathrm{C}$, NAP buffer as described in text, RNAlater is a commercial product from Qiagen, the ethanol was at 95\%, and Longmire refers to the lysis buffer described in Longmire et al. (1997). RNA extracts from blood and Longmire buffer were very degraded and/or had low concentrations, such that the BioAnalyzer could not estimate RIN values (NA) or were not run (NR). N = 3 samples (three different rats) for each combination of tissue 9 condition at times 7 or 8 weeks and for each time point in the postmortem DNA stability, except for muscle in RNAlater $(\mathrm{N}=1$ ). For the 10 -month time point, $\mathrm{N}=6$ (3 rats 92 replicates per rat) for each combination of tissue 9 condition, except $n=4$ for tail in ethanol

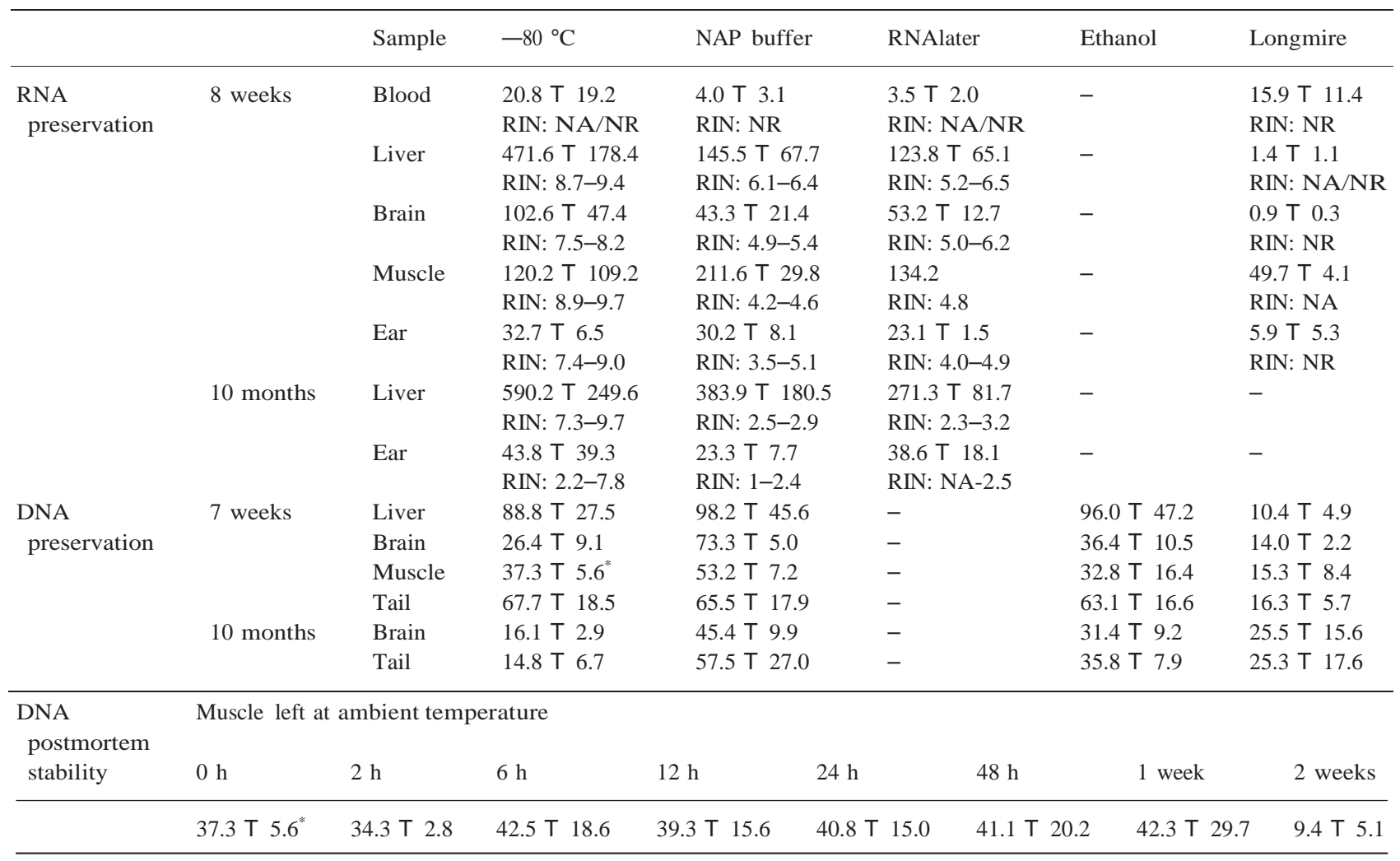

*Same sample. 


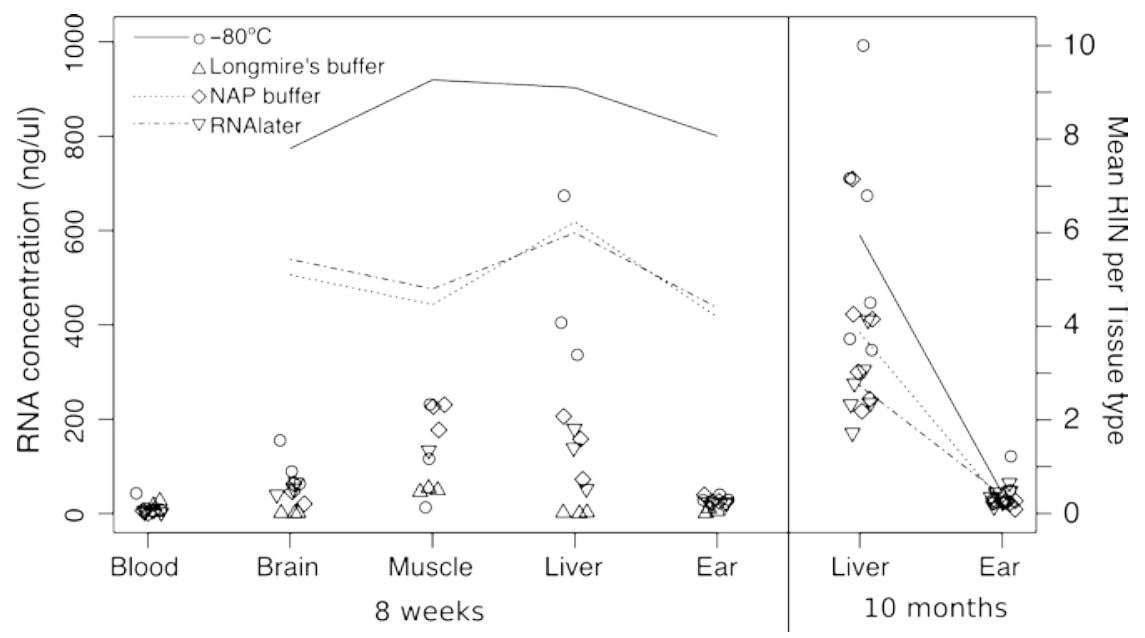

Fig. 1 RNA concentration and quality from various rat sample types under different preservation conditions. RNA concentrations (left y-axis) are represented with symbols. The mean of the RNA integrity number (RIN) (right y-axis) is represented with a line for each preservation condition. For plotting purposes, RIN values for very degraded samples were all considered 0 . Two muscle replicates are not included (see text). Samples stored at $-80{ }^{\circ} \mathrm{C}$ yielded the highest RNA concentrations and little degradation, reflected in high RIN values for all sample types. The samples preserved in RNAlater and in NAP buffer were all partially degraded and had very similar quality and quantity values for any given sample type. Liver had the highest RNA concentrations, and ear the lowest. Samples in Longmire buffer and noncryopreserved blood were completely degraded.
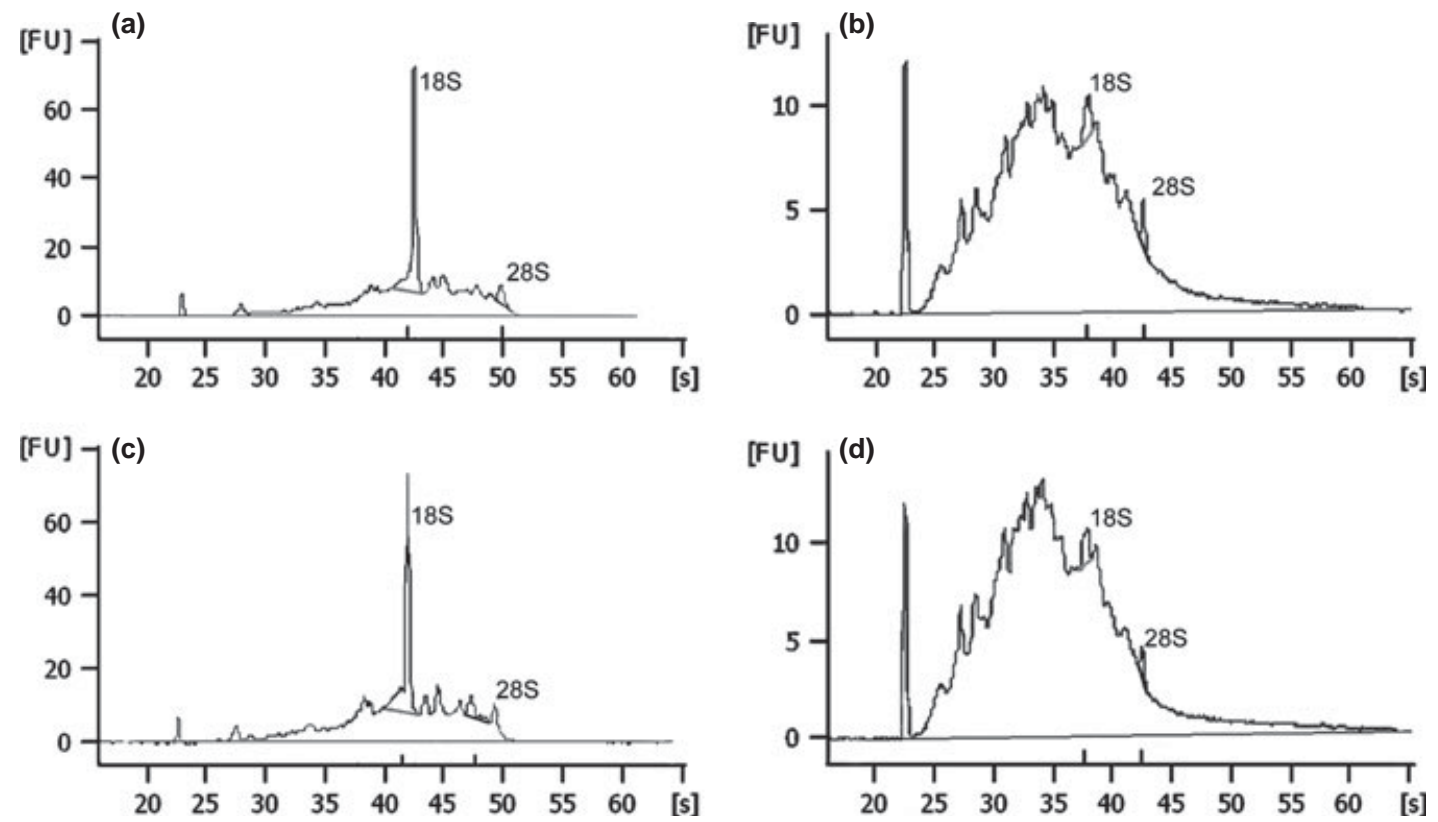

Fig. 2 BioAnalyzer profiles of RNA from liver preserved for 8 weeks or 10 months, respectively, in (a, b) RNAlater and (c, d) NAP buffer. Samples preserved in the two different buffers had similar electrophoretic profiles within a time period, with a clear $18 \mathrm{~S}$ peak, but a very degraded 28S peak, and similar RIN values of 6.3 and 6.1, respectively, after 8 weeks.

RNAlater or NAP buffer for 8 weeks (Table 1; Fig. 1). Samples preserved in NAP buffer did not significantly differ in RNA concentration from those preserved in RNAlater $(\mathrm{P}=0.65)$. After 10 months, cryopreserved samples retained a higher RNA concentration, and RNA concentrations still did not differ between NAP buffer and RNAlater $(\mathrm{P}=0.90)$. After 10 months, the difference in RNA quality was much greater for cryopreserved samples than for either preserving buffer (Table 1), and so was RNA quantity. 
The sample type had a significant effect on the RNA quality $(\mathrm{P}<0.001)$ and quantity $(\mathrm{P}<0.001)$ in samples preserved for 8 weeks. Liver was the tissue that yielded the highest RNA concentration and quality, whereas ear samples yielded the lowest (Fig. 1). Noncryopreserved blood and samples in Longmire buffer were completely degraded (Fig. 1), as indicated by their absorbance curves on NanoDrop and by their BioAnalyzer profiles (results not shown). The very low RNA concentrations registered by the NanoDrop were probably artefacts due to the concentrations being below the lower limit of sensitivity of the machine. Sample type also had a significant effect on both RNA quality $(\mathrm{P}=0.046)$ and quantity $(\mathrm{P}<0.001)$ after 10 months, although only liver and ear types could be compared.

\section{DNA preservation}

After both 7 weeks and 10 months at ambient temperature, all samples from all combinations of sample type and preservation methods yielded high molecular weight DNA (Fig. 3). After 7 weeks, DNA extractions from samples in 95\% ethanol had degraded more than those from NAP buffer or Longmire buffer (Fig. 3). After 10 months, more degradation was observed in both brain and tail for all conditions, but high molecular weight DNA was also still present in all samples tested. Preservation condition and sample type had significant effects on DNA concentration ( $\mathrm{P}<0.001$ in both cases). Within the 7-week samples, DNA concentration from samples preserved in Longmire buffer was 4.4 times lower than

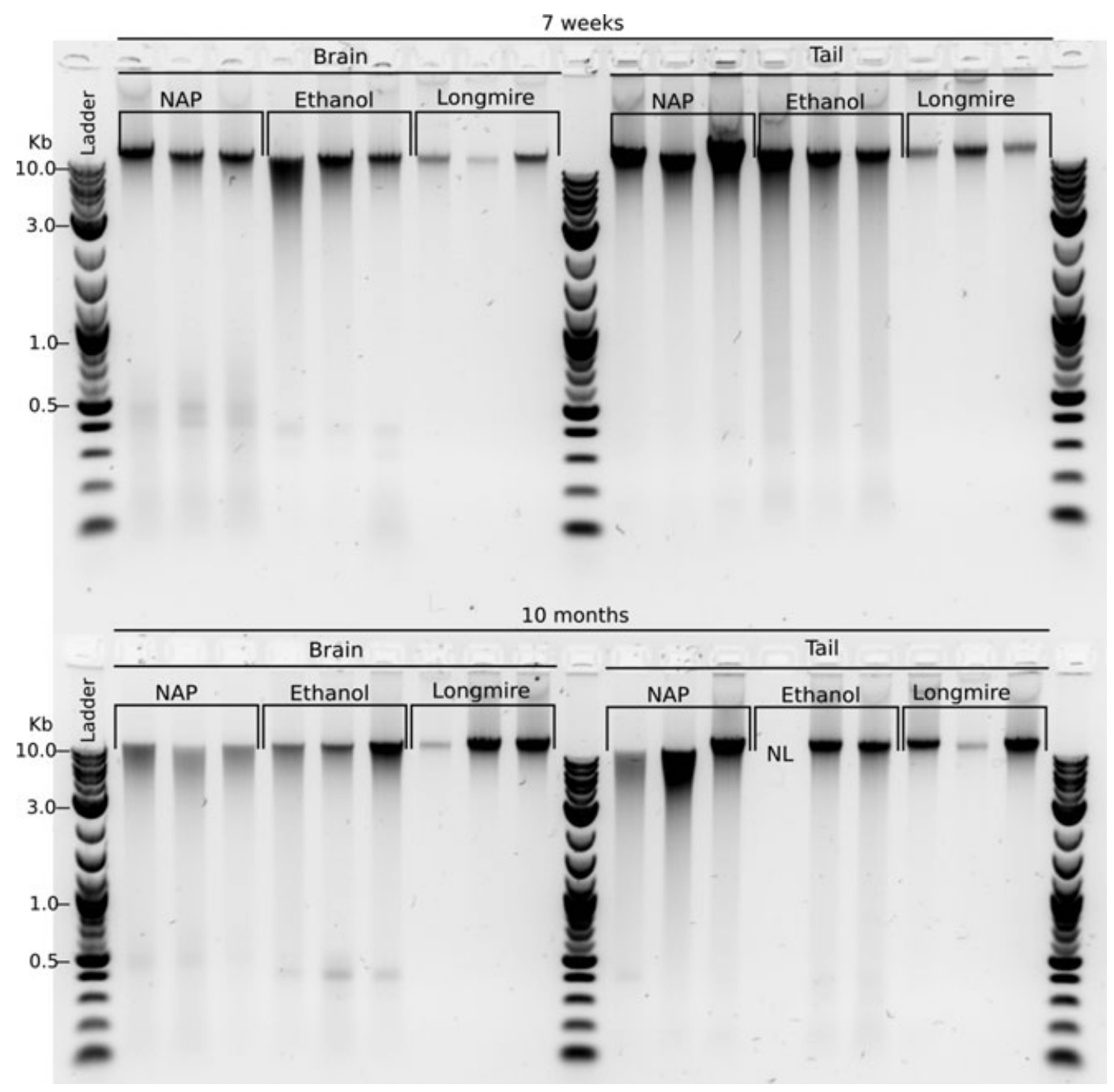

Fig. 3 DNA from brain and tail tissue preserved in NAP buffer, 95\% ethanol and Longmire buffer. After 7 weeks (top row) and 10 months (bottom row) at ambient temperature, it was possible to recover high molecular weight DNA in all cases, although the samples preserved in the NAP buffer and 95\% ethanol yielded brighter bands than those preserved in the Longmire buffer. Extractions from samples preserved in 95\% ethanol showed more degradation than those from the NAP and Longmire buffers. A well that was not loaded is labelled 'NL'. 
in the other conditions (Table 1). DNA concentrations from samples preserved in NAP buffer were 1.3 times higher than those from 95\% ethanol $(\mathrm{P}=0.01)$ and cryopreservation $(\mathrm{P}=0.03$ ) (Table 1$)$. Liver yielded 2.1 times higher DNA concentrations than muscle $(\mathrm{P}<0.001)$, and 1.4 times higher concentration than the tail, although this difference was not significant (Table 1). After 10 months (Table 1), DNA concentration was still significantly higher for samples preserved in NAP buffer than for those preserved in either 95\% ethanol ( $\mathrm{P}=0.043)$ or cryopreserved $(\mathrm{P}<0.001)$. We found no significant differences in DNA concentration between the two sample types compared after 10 months (tail and brain).

\section{Postmortem stability of DNA}

Agarose gels indicated that large DNA molecules persisted at high concentrations in nonpreserved muscle samples left at ambient temperature for up to 1 week (Table 1; Fig. 4). We detected DNA degradation just $6 \mathrm{~h}$ postmortem. After 2 weeks, none of the samples showed any high molecular weight DNA (Fig. 4).

\section{Discussion}

\section{RNA preservation}

Here, we tested several methods for RNA preservation that could be used in field expeditions where samples need to be stored at ambient temperature. RNA from animals in the field can be used for multiple types of studies, including expression analyses and transcriptome sequencing. Transcriptome sequencing is likely to be more robust to some amount of RNA degradation. Preservation of RNA under field conditions has only recently become an issue as these types of studies have become more accessible through new NGS technologies. There are relatively few publications directly addressing RNA preservation under field conditions (Table 2). Most of the studies we could find either used a commercial RNA preservation product within the specifications of that product, and subjected their samples to room temperature for only $12-72 \mathrm{~h}$. There are three notable exceptions, one in which whole butterflies were preserved in RNAlater for 10 days (Gayral et al. 2011), a second in which rat liver was kept in RNAlater for 15 days (Kasahara et al. 2006) and another in which hairs were stored in RNAlater for up to 12 weeks (Bradley et al. 2005; Table 2). Here, we showed that the economical, homemade NAP buffer was as effective as RNAlater for preserving RNA quality and quantity for 8 weeks and 10 months. Although the preservation was the same between RNAlater and NAP buffer, the RNA did degrade through time, and the RIN values at 10 months were much lower than those after 8 weeks. None of the conditions we tested on blood yielded RNA in useful quality and/or quantity for expression or transcriptomic studies. However, others have shown that RNA in blood is stable in several commercial products at room temperature on a much shorter timescale and can be used for NGS under those conditions (i.e. preservation time 24 h, Schwochow et al. 2012; Table 2) and in expression studies (i.e. preservation time 5 days, Rainen et al. 2002; Table 2).

\section{DNA preservation}

Several studies have reported high molecular weight or usable DNA from a variety of tissues preserved in a variety of ways compatible with extended field work, including a variety of salt- or alcohol-based solutions

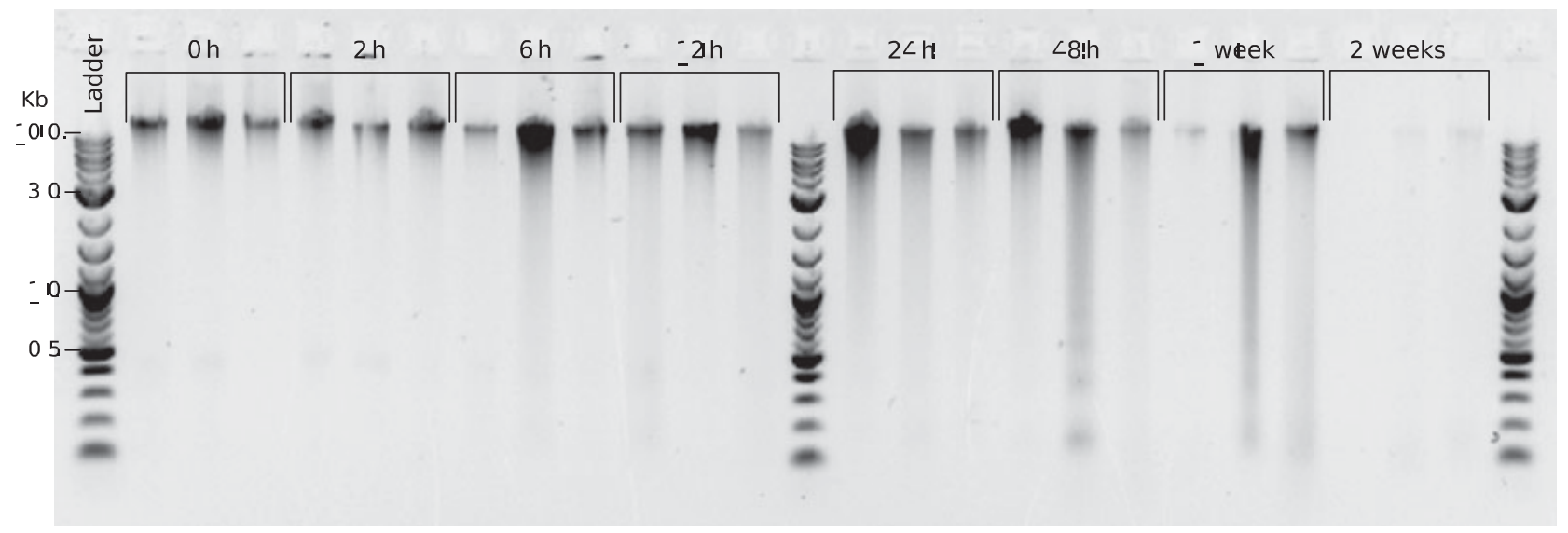

Fig. 4 DNA extractions from nonpreserved muscle tissue left at ambient temperature for up to 2 weeks. High molecular weight DNA was present in all samples from 0 h, 2 h, 6 h, 12 h, 24 h, 48 h and 1 week, but not in samples from 2 weeks. DNA degradation started to be apparent on the gel at $6 \mathrm{~h}$. 
Table 2 Review of previous studies analysing preserved RNA quantity or quality. Due to the small number of studies, data from all animals (vertebrate and invertebrate) were included

\begin{tabular}{|c|c|c|c|c|c|c|c|}
\hline Tissue & Taxa & Condition & Preservation & Time & Quality test & RNA preservation & Reference \\
\hline \multirow[t]{7}{*}{ Blood } & \multirow[t]{5}{*}{ Carnivora } & $\begin{array}{l}12-24 \mathrm{~h} \text { at } \mathrm{RT} \\
\text { then }-20^{\circ} \mathrm{C}\end{array}$ & RNAlater & $12-24 \mathrm{~h}$ & Nanodrop; BioAnalyzer & $\begin{array}{l}\text { 5.0-43.9 Ig/500 IL blood } \\
\text { RIN: } 4.6 \text { T } 2.3\end{array}$ & $\begin{array}{l}\text { Schwochow et al. } \\
\text { (2012) }\end{array}$ \\
\hline & & $\begin{array}{l}12-24 \mathrm{~h} \text { at } \mathrm{RT} \\
\text { then }-20^{\circ} \mathrm{C}\end{array}$ & RNAprotect & $12-24 \mathrm{~h}$ & Nanodrop; BioAnalyzer & $\begin{array}{l}0.0-6.2 \text { lg/500 1L blood } \\
\text { RIN: } 6.9 \text { T } 2.6\end{array}$ & $\begin{array}{l}\text { Schwochow et al. } \\
\text { (2012) }\end{array}$ \\
\hline & & $\begin{array}{l}12-24 \mathrm{~h} \text { at } \mathrm{RT} \\
\text { then }-20{ }^{\circ} \mathrm{C}\end{array}$ & TRIzol LS & $12-24 \mathrm{~h}$ & Nanodrop; BioAnalyzer & $\begin{array}{l}0.2-15.1 \text { lg/500 IL blood } \\
\text { RIN: } 6.2 \text { T } 2.9\end{array}$ & $\begin{array}{l}\text { Schwochow et al. } \\
\text { (2012) }\end{array}$ \\
\hline & & $\begin{array}{l}12-24 \mathrm{~h} \text { at } \mathrm{RT} \\
\text { then }-20^{\circ} \mathrm{C}\end{array}$ & PAXgene & $12-24 \mathrm{~h}$ & $\begin{array}{l}\text { Nanodrop; BioAnalyzer; } \\
\text { Sequencing in 1/16th }\end{array}$ & $\begin{array}{l}0.1-10.2 \mathrm{lg} / 500 \mathrm{IL} \text { blood } \\
\text { RIN: } 7.7 \mathrm{~T} 1.2\end{array}$ & $\begin{array}{l}\text { Schwochow et al. } \\
\text { (2012) }\end{array}$ \\
\hline & & & & & lanes of a 454 GS FLX Titanium & $\begin{array}{l}\text { Successful } 454 \text { sequencing of } \\
\text { cDNA libraries from samples with } \\
\text { RIN >7 }\end{array}$ & \\
\hline & \multirow[t]{2}{*}{ Human } & \multirow[t]{2}{*}{$4,20,22{ }^{\circ} \mathrm{C}$} & \multirow[t]{2}{*}{$\begin{array}{l}\text { PAXgene } \\
\text { tubes }\end{array}$} & \multirow[t]{2}{*}{$0,1,3,5,7 \mathrm{~d}$} & \multirow{2}{*}{$\begin{array}{l}\text { BioAnalyzer; Northern } \\
\text { blot of GAPDH; IFN IEF } \\
\text { SS and p53 gene transcripts }\end{array}$} & $\begin{array}{l}\text { RNA integrity high for at least } 5 \mathrm{~d} \\
\text { at } 22{ }^{\circ} \mathrm{C}\end{array}$ & \multirow[t]{2}{*}{$\begin{array}{l}\text { Rainen et al. } \\
\text { (2002) }\end{array}$} \\
\hline & & & & & & $\begin{array}{l}\text { Bands in Northern blot identifiable } \\
\text { for at least } 7 \mathrm{~d} \text { at } 22^{\circ} \mathrm{C}\end{array}$ & \\
\hline $\begin{array}{l}\text { Blood } \\
\text { (Filtered) }\end{array}$ & Carnivora & $\begin{array}{l}12-24 \mathrm{~h} \text { at } \mathrm{RT} \\
\text { then }-20{ }^{\circ} \mathrm{C}\end{array}$ & RNA later & $0,1,3,5,7 \mathrm{~d}$ & Nanodrop; BioAnalyzer & $\begin{array}{l}0.1-3.7 \mathrm{lg} / 500 \mathrm{lL} \text { blood } \\
\text { RIN: } 7.6 \mathrm{~T} 1.9\end{array}$ & $\begin{array}{l}\text { Schwochow et al. } \\
\text { (2012) }\end{array}$ \\
\hline Hair & Human & $\mathrm{RT}$ & RNAlater & $1,3,6,12$ weeks & $\begin{array}{l}\text { Amplification of b-actin (318-bp) } \\
\text { and MITF (314-bp) segments } \\
\text { from cDNA }\end{array}$ & $\begin{array}{l}\text { Consistent amplification of MITF } \\
\text { and b-actin from three hairs through } 6 \mathrm{w}\end{array}$ & $\begin{array}{l}\text { Bradley et al. } \\
\text { (2005) }\end{array}$ \\
\hline \multirow[t]{6}{*}{ Liver } & \multirow[t]{5}{*}{ Mouse } & $\mathrm{RT}$ & RNAlater & $15 \mathrm{~min}, 1 \mathrm{~h}, 4 \mathrm{~h}, 24 \mathrm{~h}$ & 18S, 28S bands on agarose gel & RNA stable for $24 \mathrm{~h}$ & Vincek et al. (2003) \\
\hline & & RT & $100 \%$ ethanol & 15 min, 1 h, 4 h, 24 h & $18 \mathrm{~S}, 28 \mathrm{~S}$ bands on agarose gel & RNA stable for $24 \mathrm{~h}$ & Vincek et al. (2003) \\
\hline & & RT & $0.9 \% \mathrm{NaCl}$ & 15 min, 1 h, 4 h, 24 h & 18S, 28S bands on agarose gel & RNA stable for $24 \mathrm{~h}$ & Vincek et al. (2003) \\
\hline & & RT & Xylene & $15 \mathrm{~min}, 1 \mathrm{~h}, 4 \mathrm{~h}, 24 \mathrm{~h}$ & 18S, 28S bands on agarose gel & RNA degrades in $1-4 \mathrm{~h}$ & Vincek et al. (2003) \\
\hline & & RT & $10 \%$ formalin & 15 min, 1 h, 4 h, 24 h & $18 \mathrm{~S}, 28 \mathrm{~S}$ bands on agarose gel & RNA degrades in $<15$ min & Vincek et al. (2003) \\
\hline & Rat & RT & RNAlater & $1,3,8,15 \mathrm{~d}$ & $\begin{array}{l}\text { 28S/18S ratio on agarose gel; } \\
\text { b-Actin mRNA quantified } \\
\text { by RT-PCR }\end{array}$ & $\begin{array}{l}\text { Clear } 18 \mathrm{~S} \text { and } 28 \mathrm{~S} \text { bands through } \\
\text { day } 15 \\
\text { Approximately, 30\% reduction } \\
\text { in b-actin mRNA copies by day } 15\end{array}$ & $\begin{array}{l}\text { Kasahara et al. } \\
\text { (2006) }\end{array}$ \\
\hline \multirow[t]{3}{*}{$\begin{array}{l}\text { Whole } \\
\text { animal }\end{array}$} & \multirow[t]{2}{*}{$\begin{array}{l}\text { Artemia } \\
\text { spp. }\end{array}$} & $5{ }^{\circ} \mathrm{C}$ & RNAlater & $0,1,2,4$ and $8 \mathrm{~m}$ & Quantification on fluorometer & $\begin{array}{l}\text { Stable concentration for at least } \\
4 \mathrm{~m}\end{array}$ & Gorokhova (2005) \\
\hline & & $19-22{ }^{\circ} \mathrm{C}$ & RNAlater & $0,1,2,4$ and $8 \mathrm{~m}$ & Quantification on fluorometer & $\begin{array}{l}\text { Stable concentration for at least } \\
1 \mathrm{~m}\end{array}$ & Gorokhova (2005) \\
\hline & Butterfly & RT & RNAlater & $10 \mathrm{~d}$ & $\begin{array}{l}\text { BioAnalyzer; Illumina } \\
\text { library preparation }\end{array}$ & $\begin{array}{l}\text { Very good RNA quality; } \\
\text { Successful preparation of } \\
\text { Illumina cDNA libraries }\end{array}$ & Gayral et al. (2011) \\
\hline
\end{tabular}

min, minutes; h, hours; d, days; w, weeks; m, months; RT, room temperature. 
Table 3 Survey of some studies reporting on DNA preservation in birds and mammals over weeks or months timescales

\begin{tabular}{|c|c|c|c|c|c|c|}
\hline Tissue & Taxon & Condition & Time & Quality test & Results & Reference \\
\hline \multirow[t]{5}{*}{ Blood } & Bird & Dried on glass & $6 \mathrm{w}$ & $\begin{array}{l}\text { Agarose gel; } \\
\text { Southern blot }\end{array}$ & HMW DNA & Seutin et al. (1991) \\
\hline & Bird & $\begin{array}{l}\text { Lysis buffer } \\
\text { (Applied } \\
\text { Biosystems) }\end{array}$ & $6 \mathrm{w}$ & $\begin{array}{l}\text { Agarose gel; } \\
\text { Southern blot }\end{array}$ & HMW DNA & Seutin et al. (1991) \\
\hline & Bird & Queen's lysis buffer & $24 \mathrm{w}$ & $\begin{array}{l}\text { Agarose gel; } \\
\text { Southern blot }\end{array}$ & HMW DNA & Seutin et al. (1991) \\
\hline & Human & Dried on filter paper & $4.5 \mathrm{~m}$ & Agarose gel & HMW DNA & McCabe et al. (1987) \\
\hline & Human & Dried on cloth & $4 \mathrm{y}$ & $\begin{array}{l}\text { Agarose gel; Southern } \\
\text { blot of HinfI digestion }\end{array}$ & $\begin{array}{l}\text { HMW DNA; } \\
\text { unique } \\
\text { fingerprinting }\end{array}$ & Gill et al. (1985) \\
\hline $\begin{array}{l}\text { Peripheral } \\
\text { blood } \\
\text { leucocytes }\end{array}$ & Elephant & LST buffer & $1,4,6,8 \mathrm{w}$ & $\begin{array}{l}\text { PCR of mitochondrial } \\
\text { (520-bp) and nuclear } \\
\text { (260-bp) regions }\end{array}$ & $\begin{array}{l}\text { Successful PCR's } \\
\text { after } 6 \mathrm{w}\end{array}$ & $\begin{array}{l}\text { Muralidharan \& } \\
\text { Wemmer (1994) }\end{array}$ \\
\hline \multirow[t]{2}{*}{ Brain } & Bird & DMSO & $6 \mathrm{w}$ & $\begin{array}{l}\text { Agarose gel; } \\
\text { Southern blot }\end{array}$ & HMW DNA & Seutin et al. (1991) \\
\hline & Bird & Ethanol $70 \%$ & $6 \mathrm{w}$ & $\begin{array}{l}\text { Agarose gel; } \\
\text { Southern blot }\end{array}$ & $\begin{array}{l}\text { No DNA } \\
\text { recovered }\end{array}$ & Seutin et al. (1991) \\
\hline \multirow[t]{5}{*}{ Liver } & Mouse & DMSO & $\begin{array}{l}\text { 1, 3, } 5 \mathrm{~d} ; \\
\text { 1, 2, 3, 4, } 6 \mathrm{w} ; \\
2,3,4,5,6 \mathrm{~m} ; \\
2 \mathrm{y}\end{array}$ & $\begin{array}{l}\text { Agarose gel, PCR of } \\
\text { cyt b }\end{array}$ & $\begin{array}{l}\text { HMW DNA; } \\
\text { Successful PCR }\end{array}$ & Kilpatrick (2002) \\
\hline & Mouse & $95 \%$ ethanol & $\begin{array}{l}\text { 1, 3, } 5 \mathrm{~d} \\
1,2,3,4,6 \mathrm{w} \\
2,3,4,5,6 \mathrm{~m} ; \\
2 \mathrm{y}\end{array}$ & $\begin{array}{l}\text { Agarose gel, PCR of } \\
\text { cyt b }\end{array}$ & $\begin{array}{l}\text { HMW DNA; } \\
\text { Successful PCR }\end{array}$ & Kilpatrick (2002) \\
\hline & Mouse & Longmire buffer & $\begin{array}{l}1,3,5 \mathrm{~d} ; \\
1,2,3,4,6 \mathrm{w} ; \\
2,3,4,5,6 \mathrm{~m} ; \\
2 \mathrm{y}\end{array}$ & $\begin{array}{l}\text { Agarose gel, PCR of } \\
\text { cyt b }\end{array}$ & $\begin{array}{l}\text { HMW DNA; } \\
\text { Successful PCR }\end{array}$ & Kilpatrick (2002) \\
\hline & Bird & DMSO & $6,24 \mathrm{w}$ & $\begin{array}{l}\text { Agarose gel; } \\
\text { Southern blot }\end{array}$ & HMW DNA & Seutin et al. (1991) \\
\hline & Bird & Ethanol, 70\% & $6,11 \mathrm{w}$ & $\begin{array}{l}\text { Agarose gel; } \\
\text { Southern blot }\end{array}$ & $\begin{array}{l}\text { Significant DNA } \\
\text { degradation }\end{array}$ & Seutin et al. (1991) \\
\hline \multirow[t]{10}{*}{ Muscle } & Bird & DMSO & $6 \mathrm{w}$ & $\begin{array}{l}\text { Agarose gel; } \\
\text { Southern blot }\end{array}$ & HMW DNA & Seutin et al. (1991) \\
\hline & Bird & Ethanol $70 \%$ & $6 \mathrm{w}$ & $\begin{array}{l}\text { Agarose gel; } \\
\text { Southern blot }\end{array}$ & $\begin{array}{l}\text { No DNA } \\
\text { recovered }\end{array}$ & Seutin et al. (1991) \\
\hline & Human & Dehydration & $4,7,14,28 \mathrm{~d}$ & STR genotyping & Full profile & $\begin{array}{l}\text { Allen-Hall \& McNevin } \\
\text { (2012) }\end{array}$ \\
\hline & Human & DMSO & $4,7,14,28 d$ & STR genotyping & Full profile & $\begin{array}{l}\text { Allen-Hall \& McNevin } \\
\text { 2012; }\end{array}$ \\
\hline & Human & DNAgard & $4,7,14,28 d$ & STR genotyping & Full profile & $\begin{array}{l}\text { Allen-Hall \& McNevin } \\
\text { (2012) }\end{array}$ \\
\hline & Human & Ethanol $70 \%$ & $4,7,14,28 d$ & STR genotyping & Full profile & $\begin{array}{l}\text { Allen-Hall \& McNevin } \\
\text { (2012) }\end{array}$ \\
\hline & Human & $\begin{array}{l}\text { Ethanol } 70 \%+ \\
0.1 \text { mм EDTA }\end{array}$ & $4,7,14,28 d$ & STR genotyping & Full profile & $\begin{array}{l}\text { Allen-Hall \& McNevin } \\
\text { (2012) }\end{array}$ \\
\hline & Human & $\begin{array}{l}\text { Genotek Tissue } \\
\text { Stabilising Kit }\end{array}$ & $4,7,14,28 d$ & STR genotyping & Full profile & $\begin{array}{l}\text { Allen-Hall \& McNevin } \\
\text { (2012) }\end{array}$ \\
\hline & Human & Solid $\mathrm{NaCl}$ & $4,7,14,28 \mathrm{~d}$ & STR genotyping & $\begin{array}{l}\text { Full profile up } \\
\text { to } 7 \mathrm{~d}\end{array}$ & $\begin{array}{l}\text { Allen-Hall \& McNevin } \\
\text { (2012) }\end{array}$ \\
\hline & Human & RNAlater & $4,7,14,28 d$ & STR genotyping & $\begin{array}{l}\text { Frequent allelic } \\
\text { dropout }\end{array}$ & $\begin{array}{l}\text { Allen-Hall \& McNevin } \\
\text { (2012) }\end{array}$ \\
\hline
\end{tabular}


Table 3 (Continued)

\begin{tabular}{|c|c|c|c|c|c|c|}
\hline Tissue & Taxon & Condition & Time & Quality test & Results & Reference \\
\hline & Human & TENT buffer & $4,7,14,28 d$ & STR genotyping & $\begin{array}{l}\text { Frequent allelic } \\
\text { dropout }\end{array}$ & $\begin{array}{l}\text { Allen-Hall \& McNevin } \\
\text { (2012) }\end{array}$ \\
\hline \multirow[t]{14}{*}{$\begin{array}{l}\text { Muscle } \\
\text { and skin }\end{array}$} & Pig & $\begin{array}{l}\text { Dried at } 70{ }^{\circ} \mathrm{C} \text { for } \\
72 \mathrm{~h}\end{array}$ & $2 \mathrm{w}, 2 \mathrm{~m}$ & PCR of IGF-1 (642 bp) & $100 \%$ PCR success & Michaud \& Foran (2011) \\
\hline & Pig & Ethanol $70 \%$ & $2 \mathrm{w}, 2 \mathrm{~m}$ & PCR of IGF-1 (642 bp) & $100 \%$ PCR success & Michaud \& Foran (2011) \\
\hline & Pig & Isopropanol, 70\% & $2 \mathrm{w}, 2 \mathrm{~m}$ & PCR of IGF-1 (642 bp) & $100 \%$ PCR success & Michaud \& Foran (2011) \\
\hline & Pig & RNAlater & $2 \mathrm{w}, 2 \mathrm{~m}$ & PCR of IGF-1 (642 bp) & $100 \%$ PCR success & Michaud \& Foran (2011) \\
\hline & Pig & Silica desiccant & $2 \mathrm{w}, 2 \mathrm{~m}$ & PCR of IGF-1 (642 bp) & $100 \%$ PCR success & Michaud \& Foran (2011) \\
\hline & Pig & $-80^{\circ} \mathrm{C}$ & $1 \mathrm{w}, 2 \mathrm{~m}, 6 \mathrm{~m}$ & PCR of IGF-1 (642 bp) & $\begin{array}{l}\text { 75\%; } 100 \% ; 50 \% \\
\text { PCR success }\end{array}$ & Michaud \& Foran (2011) \\
\hline & Pig & DMSO & $1 \mathrm{w}, 2 \mathrm{~m}, 6 \mathrm{~m}$ & PCR of IGF-1 (642 bp) & $\begin{array}{l}\text { 100\%; } 100 \% ; 75 \% \\
\text { PCR success }\end{array}$ & Michaud \& Foran (2011) \\
\hline & Pig & Ethanol, $40 \%$ & $1 \mathrm{w}, 2 \mathrm{~m}, 6 \mathrm{~m}$ & PCR of IGF-1 (642 bp) & $\begin{array}{l}\text { 100\%; } 100 \% ; 0 \% \\
\text { PCR success }\end{array}$ & Michaud \& Foran (2011) \\
\hline & Pig & Ethanol, 70\% & $1 \mathrm{w}, 2 \mathrm{~m}, 6 \mathrm{~m}$ & PCR of IGF-1 (642 bp) & $\begin{array}{l}\text { 100\%; } 50 \% ; 50 \% \\
\text { PCR success }\end{array}$ & Michaud \& Foran (2011) \\
\hline & Pig & Ethanol, $100 \%$ & $1 \mathrm{w}, 2 \mathrm{~m}, 6 \mathrm{~m}$ & PCR of IGF-1 (642 bp) & $\begin{array}{l}\text { 100\%; } 100 \% ; 50 \% \\
\text { PCR success }\end{array}$ & Michaud \& Foran (2011) \\
\hline & Pig & Isopropanol, 70\% & $1 \mathrm{w}, 2 \mathrm{~m}, 6 \mathrm{~m}$ & PCR of IGF-1 (642 bp) & $\begin{array}{l}\text { 100\%; } 100 \% ; 25 \% \\
\text { PCR success }\end{array}$ & Michaud \& Foran (2011) \\
\hline & Pig & Isopropanol, $100 \%$ & $1 \mathrm{w}, 2 \mathrm{~m}, 6 \mathrm{~m}$ & PCR of IGF-1 (642 bp) & $\begin{array}{l}\text { 100\%; } 100 \% ; 25 \% \\
\text { PCR success }\end{array}$ & Michaud \& Foran (2011) \\
\hline & Pig & Silica desiccant, $2.5 \mathrm{~g}$ & $1 \mathrm{w}, 2 \mathrm{~m}, 6 \mathrm{~m}$ & PCR of IGF-1 (642 bp) & $\begin{array}{l}\text { 100\%; } 100 \% ; 0 \% \\
\text { PCR success }\end{array}$ & Michaud \& Foran (2011) \\
\hline & Pig & $\begin{array}{l}\text { Silica desiccant, } \\
12.5 \mathrm{~g}\end{array}$ & $1 \mathrm{w}, 2 \mathrm{~m}, 6 \mathrm{~m}$ & PCR of IGF-1 (642 bp) & $\begin{array}{l}100 \% ; 50 \% ; 0 \% \\
\text { PCR success }\end{array}$ & Michaud \& Foran (2011) \\
\hline
\end{tabular}

d, days; w, weeks; m, months; y, years; HMW, high molecular weight, bp, base pairs; PCR, polymerase chain reaction.

and desiccation procedures (Table 3). The NAP buffer preserved DNA quality and quantity slightly better than both 95\% ethanol and cryopreservation for at least 7 weeks. This could be because EDTA, which is present in the NAP buffer, might protect the DNA during the extraction procedure. In another study, Kilpatrick (2002) showed that addition of EDTA to ethanol prevented DNA degradation during the extraction process. He also recorded that the use of salt-based buffers that contained EDTA, such as DMSO or Longmire, could preserve high molecular weight DNA after noncryogenic storage of tissue samples for long times (at least 2 years) at room temperature. Therefore, it is likely that the DNA could be stable in NAP buffer at room temperature for much longer than the 10 months demonstrated here, perhaps even years. Longmire buffer is a lysis buffer in which DNA can accumulate in the solution with time (Kilpatrick 2002). This could explain the low DNA quantity yields we obtained from tissue extractions preserved in this buffer. Nevertheless, DNA quality was high in samples preserved in Longmire buffer.

Useful quantities and qualities of DNA were observed here in nonpreserved postmortem muscle tissue for up to 1 week. Other authors have also found that high molecular weight DNA in some tissues, such as in blood or kidney, degrade very fast after 1 week, whereas in others, such as brain, lasts longer (Ludes et al. 1993). Although these times will vary depending on external humidity and temperature, sampling from recently dead carcasses in the field can be a potential source for high molecular weight DNA.

\section{Sample types}

RNA and DNA stability can be tissue dependent (RNA: Bahar et al. 2007; Seear \& Sweeney 2008; DNA: B frr et al. 1988; Ludes et al. 1993). Our results show that liver yielded the best quality and quantity DNA and RNA among the sample types tested. In vertebrates, liver is the next best tissue after testis that yields the highest quantity of high molecular weight DNA (Wong et al. 2012). Liver also offers a lot of tissue quantity for DNA extraction, as it is a big organ, but it has the risk of nucleic acid degradation due to its high nuclease content (Wong et al. 2012). Skeletal muscle is less prone to DNA degradation and it is also abundant, but usually yields less DNA due to the tough nature of the muscle fibres (Wong et al. 2012). In this study, we observed unex- 
pected electrophoretic profiles for two of our extracts of RNA from muscle, perhaps for this reason.

High-throughput sequencing platforms usually require initial input of high quantities of good-quality RNA or DNA. For library preparation, sequencing services generally request more than $1 \mathrm{lg}$ of nondegraded DNA and at least $1 \mathrm{Ig}$ of RNA with RIN $>7$. Other applications, such as whole-genome sequencing, recommend even larger amounts of DNA such as $1 \mathrm{mg}$ of highquality DNA (Wong et al. 2012). RIN values for liver preserved for 8 weeks in RNAlater and in NAP buffer were 5.2-6.5, slightly lower than normally recommended for transcriptome sequencing. Ear clips in RNAlater and NAP buffer yielded RNA in low quantities (mean T SD: $26.7 \mathrm{~T} 6.5 \mathrm{ng} / \mathrm{lL}$ ), but the quality was moderate (RIN: 3.5-5.1). As NGS technologies develop, their demand for high-quantity and high-quality material may be relaxed. For example, the new Smart-Seq can perform transcriptomic analysis from RNA quantities as low as $10 \mathrm{pg}$ (Goetz \& Trimarchi 2012).

\section{Conclusion}

Cryopreservation should be used whenever possible as it preserves high-quantity and good-quality RNA and DNA. However, field trips often occur in locations where cryopreservation is not possible. Under such conditions, we recommend the use of NAP buffer because it is inexpensive, easy to transport because it is nonhazardous and nonflammable, and it is possible to recover a high quantity of high molecular weight DNA and medium-quality RNA after months at ambient temperature. The limited data currently available suggest that RNA preservation varies among tissues (Fig. 1), and possibly between taxa, so it would be safest to perform a pilot study as similar to the target study as possible to determine whether a usable amount of RNA is likely to be preserved under those particular conditions. Further, NAP buffer can be used for both RNA and DNA preservation. Liver is the best source for RNA and DNA and its preservation in NAP buffer offers the potential for it to be used in NGS applications. However, if animals are not collected, the biological material that can be sampled, such as tail tip or ear clip, offers fewer possibilities for expression studies due to the low quantity of RNA, although they remain a good source for DNA.

\section{Acknowledgements}

We are grateful to Christophe Lejeusne for his advices on working with RNA in the laboratory and to Anna Cornellas and Lola Asencio for laboratory assistance. Logistical support was provided by Laboratorio de Ecología Molecular, Estación Biológica de Dorrana, CSIC (LEM-EBD), and by the Genomics Unit, CABIMER-CSIC. This work was supported by the Spanish Ministry of Science and Innovation grants CGL-11123 to IG-M and CGL2010-21524 to JAL. MCS is supported by the Spanish Ministry of Science and Innovation Predoctoral Fellowship BES2011-049186, and PBG is supported by the Spanish Ministry of Education, Culture and Sports Predoctoral Fellowship AP20105373.

\section{References}

Allen-Hall A, McNevin D (2012) Human tissue preservation for disaster victim identification (DVI) in tropical climates. Forensic Science International: Genetics, 6, 653-657.

Bahar B, Monahan FJ, Moloney AP et al. (2007) Long-term stability of RNA in post-mortem bovine skeletal muscle, liver and subcutaneous adipose tissues. BMC Molecular Biology, 8, 108.

B€r W, Kratzer A, M€chler M, Schmid W (1988) Postmortem stability of DNA. Forensic Science International, 39, 59-70.

Bradley BJ, Pastorini J, Mundy NI (2005) Successful retrieval of mRNA from hair follicles stored at room temperature: implications for studying gene expression in wild mammals. Molecular Ecology Notes, 5, 961-964.

Chen S, Zhou R, Huang Y et al. (2011) Transcriptome sequencing of a highly salt tolerant mangrove species Sonneratia alba using Illumina platform. Marine Genomics, 4, 129-136.

Dassanayake M, Haas JS, Bohnert HJ, Cheeseman JM (2009) Shedding light on an extremophile lifestyle through transcriptomics. The New Phytologist, 183, 764-775.

Elmer KR, Fan S, Gunter HM et al. (2010) Rapid evolution and selection inferred from the transcriptomes of sympatric crater lake cichlid fishes. Molecular Ecology, 19(Suppl.1), 197-211.

Gayral P, Weinert L, Chiari Y et al. (2011) Next-generation sequencing of transcriptomes: a guide to RNA isolation in nonmodel animals. Molecular Ecology Resources, 11, 650-661.

Gill P, Jeffreys AJ, Werrett DJ (1985) Forensic applications of DNA “fingerprints". Nature, 318, 577-579.

Goetz JJ, Trimarchi JM (2012) Transcriptome sequencing of single cells with Smart-Seq. Nature Biotechnology, 30, 763-765.

Gorokhova E (2005) Effects of preservation and storage of microcrustaceans in RNAlater on RNA and DNA degradation. Limnol Oceanogr Methods, 3, 143-148.

Hohenlohe PA, Bassham S, Etter PD, et al. (2010) Population genomics of parallel adaptation in threespine stickleback using sequenced RAD tags. PLoS Genetics, 6, e1000862.

Kasahara T, Miyazaki T, Nitta H (2006) Evaluation of methods for duration of RNA quality in rat liver used for transcriptome analysis. The Journal of Toxicological Sciences, 31, 509-519.

Kilpatrick CW (2002) Noncryogenic preservation of mammalian tissues for DNA extraction: an assessment of storage methods. Biochemical Genetics, 40, 53-62.

Longmire JL, Maltbie M, Baker RJ (1997) Use of "lysis buffer" in DNA isolation and its implications for museum collections. Museum of Texas Tech University, 163, 1-3.

Ludes B, Pfitzinger H, Mangin P (1993) DNA fingerprinting from tissues after variable postmortem periods. Journal of Forensic Sciences, 38, 686690.

Massie H, Samis H, Baird M (1972) The kinetics of degradation of DNA and RNA by $\mathrm{H}_{2} \mathrm{O}_{2}$. Biochimica et Biophysica Acta, 272, 539548.

McCabe ER, Huang SZ, Seltzer WK, Law ML (1987) DNA microextraction from dried blood spots on filter paper blotters: potential applications to newborn screening. Human Genetics, 75, 213-216.

Michaud CL, Foran DR (2011) Simplified field preservation of tissues for subsequent DNA analyses. Journal of Forensic Sciences, 56, 846-852. 
Muralidharan K, Wemmer C (1994) Transporting and Storing fieldcollected specimens for DNA without refrigeration for subsequent DNA extraction and analysis. BioTechniques, 17, 420-422.

Nagy ZT (2010) A hands-on overview of tissue preservation methods for molecular genetic analyses. Organisms Diversity \& Evolution, 10, 91-105.

Nietfeldt J, Ballinger R (1989) A new method for storing animal tissue prior to mtDNA extraction. BioTechniques, 7, 31-32.

Rainen L, Oelmueller U, Jurgensen S et al. (2002) Stabilization of mRNA expression in whole blood samples. Clinical Chemistry, 48, 1883-1890.

Riesgo A, Pérez-Porro AR, Carmona S, Leys SP, Giribet G (2012) Optimization of preservation and storage time of sponge tissues to obtain quality mRNA for next-generation sequencing. Molecular Ecology Resources, 12, 312-322.

Schroeder A, Mueller O, Stocker S et al. (2006) The RIN: an RNA integrity number for assigning integrity values to RNA measurements. BMC Molecular Biology, 7, 3.

Schwochow D, Serieys LEK, Wayne RK, Thalmann O (2012) Efficient recovery of whole blood RNA - a comparison of commercial RNA extraction protocols for high-throughput applications in wildlife species. BMC Biotechnology, 12, 33.

Seear PJ, Sweeney GE (2008) Stability of RNA isolated from post-mortem tissues of Atlantic salmon (Salmo salar L.). Fish Physiology and Biochemistry, 34, 19-24.

Seutin G, White B, Boag P (1991) Preservation of avian blood and tissue samples for DNA analyses. Canadian Journal of Zoology, 69, 89-92.

Vincek V, Nassiri M, Knowles J (2003) Preservation of Tissue RNA in Normal Saline. Laboratory Investigation, 83, 137-138.

Wang S, Sherman M (2006) Cervical tissue collection methods for RNA preservation: comparison of snap-frozen, ethanol-fixed, and RNAlaterfixation. Diagnostic Molecular Pathology, 15, 144-148.

Wolf JBW, Lindell J, Backstrem N (2010) Speciation genetics: current status and evolving approaches. Philosophical Transactions of the Royal Society of London. Series B, Biological Sciences, 365, 1717-1733.

Wong PB, Wiley EO, Johnson WE et al. (2012) Tissue sampling methods and standards for vertebrate genomics. GigaScience, 1, 8.

J.A.L., P.B. and M.C. conceived the study. I.G.M., J.A.L., P.B. and M.C. designed the experiment. P.B. and M.C. did laboratory work. I.G.M. did statistical analyses. M.C. wrote the manuscript with help from J.A.L., and P.B. and I.G.M. revised it.

\section{Data Accessibility}

Concentration of DNA and RNA, quality of RNA (RIN values) and concentration of DNA extracted across postmortem time series are available on DRYAD repository (doi:10.5061/dryad.8gh7p).

\section{Appendix I}

Protocol for the preparation of Nucleic Acid Preservation (NAP) Buffer

\begin{tabular}{ll}
\hline Materials & Equipment \\
\hline $\begin{array}{l}\text { EDTA disodium salt dihydrate } \\
\text { Sodium citrate trisodium salt dihydrate } \\
\text { Ammonium sulfate }\end{array}$ & $\begin{array}{l}\text { Scale } \\
\text { Weigh boat or paper } \\
\text { Magnetic stirrer with } \\
\text { heating plate } \\
\text { Stirring rod } \\
\text { Ultra-purified, molecular grade water } \\
\mathrm{H}_{2} \mathrm{SO}_{4} \text { to adjust the pH }\end{array}$ \\
$\begin{array}{l}\text { bottle or flask } \\
\text { PH reader }\end{array}$ \\
\hline
\end{tabular}

To make NAP buffer:

1 Combine $7.44 \mathrm{~g}$ of EDTA, $7.35 \mathrm{~g}$ of sodium citrate trisodium salt dihydrate, and $700 \mathrm{~g}$ of ammonium sulfate in $1 \mathrm{~L}$ of water in bottle or flask. Stir on low to moderate heat until the ammonium sulfate dissolves completely, which usually takes hours.

2 Cool to room temperature, then adjust $\mathrm{pH}$ to 5.2 with $\mathrm{H}_{2} \mathrm{SO}_{4}$.

3 Store at room temperature or keep refrigerated until aliquoted.

4 Aliquot $1.5 \mathrm{~mL}$ of buffer into $2 \mathrm{~mL}$ tubes for preservation of up to $150 \mathrm{mg}$ of sliced tissue. 